\title{
ISSUES OF KNOWLEDGE MANAGEMENT AND KNOWLEDGE TRANSFER IN CASE OF A HUNGARIAN CONSULTING COMPANY
}

\author{
Mónika Pónusz ${ }^{1}$, Anna Rittgasser ${ }^{2}$, Vivien Ágnes Nagy ${ }^{3}$, Tímea Kozma ${ }^{4}$ \\ ${ }^{1}$ Károli Gáspár University of the Reformed Church in Hungary Institute of Economics and Management, and \\ Management, ${ }^{2}$ Károli Gáspár Reformed University, Faculty of Law, Institute of Economics and Management, ${ }^{3}$ Szent \\ István University, Doctoral School of Managemenet and Business Administration, ${ }^{4}$ Budapest Business School Faculty \\ of Finance and Accounting
}

\begin{abstract}
The aim of our study is to present the current HR challenges of the Hungarian business services sector, the importance and problems of building and operating knowledge management systems, the innovation-stimulating effect of a good knowledge management system, the operation and solutions of the knowledge management system of Hungarian business consulting companies, and the related tasks. It is not our goal to further develop the theory of knowledge management systems, to invent new solutions. Instead, we want to establish the justification and problems of the topic with a short overview, and then we will draw conclusions and formulate proposals by analyzing and examining the processes applied and operating in real life. In order to process the literature and implement the above, we had an in-depth interview with the company's CEO.

In order to prove this, we tried to provide the most comprehensive literature review possible, which is not exhaustive and should be further expanded and detailed in the case of possible future research. We hope that we have succeeded in establishing the usefulness and problems of the topic and in formulating useful proposals that will increase the company's further development and innovation skills by analyzing the innovation process that will enable the implementation of the banking development project.

After examining the literature, we briefly presented the consulting firm under study. We then examined and illustrated the mapping of knowledge management in corporate strategy, which affects several areas; relationships, training and development, competencies, quality assurance and the knowledge base. The listed areas were also analyzed individually.

After this, the study turned to the practical presentation of the innovation-enhancing effect of the knowledge management system

On the employee side, a combination of maximum professionalism and value creation intent is essential. The implementation of goals, plans and developments can be based on a knowledge management system, the creators / implementers / operators of which are aware of the importance of knowledge capital, the difficulties of knowledge sharing and the impact of innovation on competitiveness.

The limitation of the research:the example of the presented company is not representative in nature, but as a relevant representative of the given business sector,one of the leading IT and business consulting companies in the country under study, its practice can be considered as best practice.

We have come to the conclusion that the examined company has a desire for continuous improvement and improvement on the part of the company management and they also support the employee initiatives for this purpose on a daily basis.

It can be stated that the innovation described by the literature is the most important development for the analyzed company, but in its internal practice and communication, new or re-examined processes appear as innovations.

In the near future, the main challenge will be to motivate and activate employees as effectively as possible, and to support alternative learning opportunities. By further developing their knowledge management system, they can ensure their ability to innovate and their leading market position. KEY WORDS: innovation; knowledge; learning; knowledge management; knowledge sharing; knowledge workers; consulting company.
\end{abstract}

\section{Introduction}

By the 21 st century, the information society has been replaced by a knowledge-based society in which the true value is human knowledge (Bencsik 2011) and traditional resources are increasingly marginalized. According to Csath et al. (2018), high-quality human and knowledge capabilities and skills are necessary for being fit to handle the ongoing economic and social challenges.

Recognizing the value of individual and organizational knowledge and implementing, operating, and retaining knowledge in a knowledge management system, while previously giving companies a competitive advantage, has now become an essential condition for survival. Lasting competitive advantage and success is made possible by the quality of the employees and the knowledge accumulated in the organization (Csiszér 2011; Bencsik and Juhász 2012).
Technological innovations are present in our everyday lives, they determine the lives of all of us. Work patterns, processes, and conditions are changing at a rapid pace, to which the HR and IT profession and all companies need to respond immediately to maintain competitiveness and survival.

The company participating in the present study is one of the leading IT and business consulting companies in Hungary. Its strategic goal is to support its customers at the highest possible level of service in the introduction of new and innovative technological solutions, as is the case with the implementation of the Instant Payment System (AFR) requirement for banking customers. Close cooperation between the banking, payment, IT development and sales areas is needed to achieve success, and in connection with this, HR activities, and within that, the knowledge management system, must properly support innovation processes. In the point of view, the actuality of current topic is indisputable, and it shows very exciting 
questions, solutions and tasks for the representatives of the participating professions.

The aim of the study is to present the current HR challenges of the Hungarian business services sector, the importance and problems of building and operating knowledge management systems, the innovationstimulating effect of a good knowledge management system, the operation and solutions of the knowledge management system of Hungarian business consulting companies, and the related tasks. The authors would like to establish the justification and problems of the topic with a short overview, and then draw conclusions and formulate proposals by analyzing and examining the processes applied and operating in real life.

Method: In order to process the literature and implement the above, a depth interview has been organized with the company's CEO.

\section{Literature, Secondary Research}

Knowledge sharing

Knowledge only gives a company a competitive advantage if it is shared by people and can flow properly within the organization. Without it, no new ideas, solutions or technological innovations can be born. Ideas that sound good in theory will often come up in discussions later as a goal, stalled or inoperable in reality because management or organizational culture and operation alone do not support it properly, or employees may be reluctant to apply it (Kleina and Stale 2019).

There are various reasons for not sharing knowledge:

- $\quad$ the worker fears that he will lose his value if he shares his knowledge, as he may easily become indispensable by losing his hidden, specialized knowledge,

$-$

$-$ share (Bencsik and Für, 2015)

no host,

don't know what and how to

$-$ cases also has administrative implications, and the employee experiences it as an unwanted burden if he has to share his knowledge and experience after the end of a project,

- Fejes's "knowledge tax" organizations, according to him, knowledge sharing is similar to paying taxes; no one likes to pay taxes, but as users of the tax, everyone has serious demands and expectations. Nonpayment of taxes, as well as non-sharing of knowledge, prevents value creation, quality improvement, development and a sense of belonging to a community, both in a community and organizations (Fejes 2015).

As can be seen from the - not exhaustive - list above, organizational culture is the foundation of a knowledge management system. Organizational and corporate culture can promote, increase and freeze creativity, collaboration, knowledge sharing and, at the same time, innovation skills also (Bencsik and Für
2015). It defines employee behavior, attitudes, corporate values, and willingness to innovate (Marosi 2015).

The elements of an organizational culture that promotes knowledge sharing are as follows:

Trust within the organization is the basis for cooperation, the flow of information, knowledge and experience. According to research by Davenport and Prusak, a lack of trust between employees and their managers is the most common obstacle to the successful operation of a knowledge management system. (Davenport and Prusak 2001)

- Organizations are made up of people, possessing the attributes of human capital; they carry the knowledge and are able to pass it on and then apply it. Managers need to develop a corporate and knowledge management culture that supports their willingness and ability to do so and guarantees continuous individual and corporate development, the achievement of individual and organizational goals.

- $\quad$ The behavior of the learning organization is the basic condition of knowledge management, because the goal of the learning organization is to develop and operate a knowledge management system. The impact of learning organizations on knowledge management will be discussed later.

A well-developed, logically structured and well-thought-out information technology system is the background of successful knowledge management, as it is the component that connects the users and that enables the collection, filtering and systematization of knowledge.

The organizational structure is the operational framework of the knowledge management system. As a first step in the implementation of knowledge management, it is often necessary to transform the structure into a flatter, more flexible structure that supports the above "ingredients" and gives them space. It is largely determined by leadership style and organizational culture (Fenyvesi et al. 2015).

Innovation

The origin of the term innovation is the work of the famous German economist Joseph Schumpeter, who described this concept in the context of economic development in an article in 1910. (Kis and Lörincz 2015) According to Schumpeter, innovation is a new combination of factors of production. The essence of his view is that an economy is a static economy where businesses merely reproduce themselves in the same form, use the same products, technologies, materials, supply the same markets, and operate in the same organization.

The essence of economic development is 
innovation, the appearance and introduction of novelty, and the entrepreneur who implements innovation plays the most important role in this process. (BMVK 2007)

Schumpeter's classification can be considered as a starting point for the concept of innovation, but in addition to the above definition, there are many definitions of innovation in the literature. In the broadest sense, it is a new, higher-quality way of meeting consumer needs. The latest definition is the one in the Oslo Manual published by the OECD (The Organization for Economic Co-operation and Development):

"Innovation is the introduction of a new or significantly improved product (good or service) or process, new marketing, method or new organizational method in business practice, workplace organization or external relations." (BMVK 2007)

In addition to product and process innovation, the definition already includes marketing and organizational innovation. (Vecsényi 2003) In interpreting this definition, innovation is recognized and exploited as a business opportunity that is also closely related to creativity.

Creativity is the ability to develop new ideas or new types of problem management and problem identification. From this perspective, innovation is the ability to solve creative problems, and enterprise is the conscious and systematic application of creativity and innovation to meet market opportunities and market needs.

Innovation is the successful creation, localization and application of novelty in the economy and society. It is not just a business goal, but the ability to innovate that has motivated humanity's development since time immemorial. (BMVK 2007)

Schumpeter has accepted the view that the most important engine of economic progress is innovation. The interaction of people-to-people relationships points to the corporate significance of knowledge management. Innovation promises success, ascension and enrichment. According to Chikán (2010), innovation is "meeting consumer needs at a new, higher level of quality". Consumer needs and market demand are constantly changing, expanding and there is fierce competition between companies to meet these needs. The success of innovation depends on consumer recognition and the degree of sustainability (Chikán 2010).

In the past, innovative companies have gained a significant competitive advantage in their segment, and today, in this rapidly changing market environment, the only possible way to survive is through continuous renewal and development. There is a positive relationship between corporate competitiveness and innovation, which is why companies innovate for the following reasons:

maintaining market share,
gaining new markets,
cost reduction,
quality improvement,
expansion of product structure,
increase production flexibility
(Chikán and Czakó 2009).
maintaining market share, cost reduction, quality improvement, expansion of product structure, increase production flexibility
Organizational developments and innovations for corporate competitiveness within the framework of innovation management keep the market moving and dynamize market players, and ultimately can change the entire industry competition (Balaton et al. 2010). The innovation strategy is an important part of a company's competitive strategy, which includes goals and measures that can help to achieve and increase a company's competitiveness and link corporate success to consumer satisfaction (Chikán 2010).

The authors distinguish between radical innovation (which means a new product, technology or organizational environment), differential innovation (which means making small improvements) and disruptive innovation (which creates a new market or value chain and also has a social impact). In the innovation process, not only technological development is the key, but also business success, so not only technological developments but also the development of business structures are needed for success and return (Chikán 2010).

According to Chikán a successful innovation strategy depends on the following factors:
- $\quad$ Efficiency of the information system: both in terms of real consumer needs and relevant technical information;

Focusing on quality: in today's fast-changing world, companies need to have an appropriate quality assurance system;

The speed of innovation: the market is very time-sensitive, faster development can be a competitive advantage in itself;

- Cooperation: formation of strategic alliances, corporate collaborations;

Tracking of externalities: safe use is a prerequisite, the product, service, technology do not endanger physical safety and the environment;

Opportunity to get out: Milestones are set during the implementation of innovation processes, and it is worthwhile to examine the return on investment (Chikán 2010).

According to the 2017 data of the European Innovation Scoreboard, Hungary's innovation performance is still below the EU average, among the moderately innovative countries.

The research results of Zoltán Sára and his colleagues also confirmed that although Hungarian business leaders are aware of the importance of innovation and innovation strategy and the innovationenhancing effect of knowledge, due to market conditions, financing problems and global competition, Hungarian SMEs they do not lead the way in innovation activities. (Sára et al. 2014) It would help a lot in their situation if, together with domestic universities and research institutes, they became innovation partners of multinational companies. In addition, regulatory and financial measures would need to be put in place as soon as possible (Kiss 2014). 


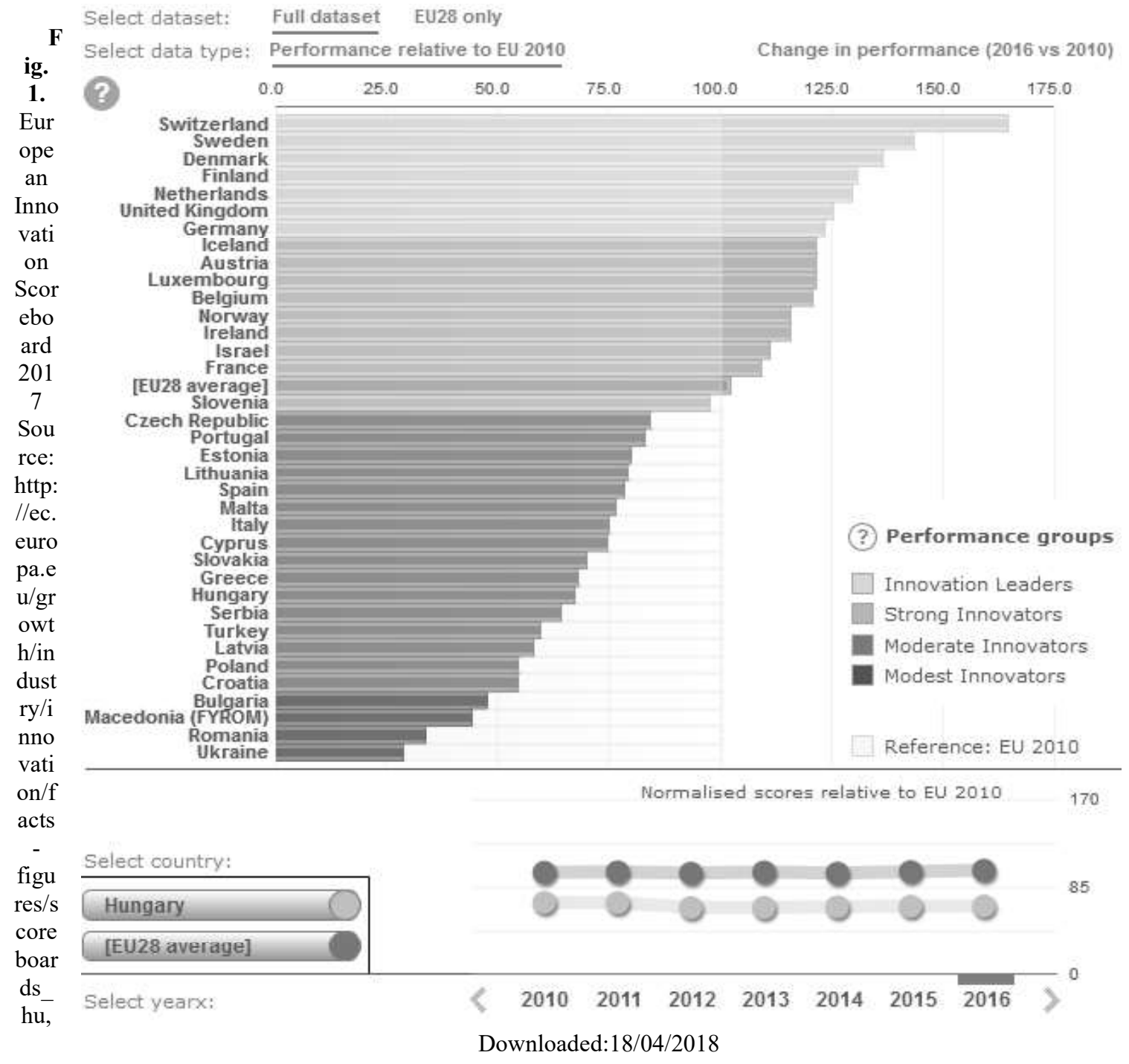

\section{The relationship between innovation and the knowledge management}

As mentioned earlier, the design and operation of knowledge management systems has now become essential for adapting to market conditions and competitiveness. Knowledge management as an activity is not a new thing; the utilization of the knowledge of the human resources working in the organization and the exchange of experience between the employees is inherent in the operation of the organization. The novelty is the recognition of the importance of knowledge management systems and the conscious design and operation of the necessary tools, systems and processes (Nathan et al. 2019).

According to Chikán, organizational knowledge that is, individual knowledge and the relationship between individuals - can be expanded in the following three ways, among others:

- learning individuals,

- the entry of more knowledgeable individuals into the organization, and
- by organizing knowledge sharing between individuals as effectively as possible (Chikán 2010).

According to Bencsik, many more solutions are possible for this, "there is also a marked difference between organizational solutions that focus on individual knowledge and its development, and organizational solutions that support organizational knowledge and its growth" (Bencsik 2015).

Knowledge management also deals with the organization and coordination of the above processes (Chikán 2010).

The primary goal of organizational knowledge is to convert individual and organizational knowledge within an organization into marketable and competitive products and services, thereby increasing a company's profitability (Sára et al. 2014).

The basis of knowledge management is the mapping, systematization, care and maintenance of human knowledge, ideas and thoughts, which also serve as the basis for innovation (Bencsik and Für 2015). Both innovation and knowledge management 
rely on internal resources, as a result of which knowledge and innovation-focused human resource management has become one of the key management challenges (Sára et al. 2014; Schwartz 2006). Innovation and knowledge management circulate in a kind of vicious circle; knowledge, which is the starting point of innovation, must be managed - striving for continuous renewal and modernization - and as a result of innovation activity, changes occur in the organization, thanks to which new knowledge is created.

Organizational characteristics supporting both innovation and knowledge management:

- common, shared vision and goals,

- advanced internal communication,

- involving employees in important decisions and planning,

- supportive leadership,

- development as a common corporate value,

- teamwork (Bencsik and Für 2015).

- a common knowledge base accessible to all.

According to Bencsik, the common elements of the conceptual framework of innovation and knowledge management, based on the definitions he examined, are the following:

- system,

- people-to-people relationship,

- development,

- feedback.

Relationships of the common elements:

- strategic thinking - systems approach,

- people-to-people relationship - network building,

- intellectual skills - development,

- knowledge transfer - knowledge network feedback."

The author also presents the connections between knowledge management and innovation models step by step (Bencsik 2018).

The characteristics of the organizational culture supporting innovation show a close overlap with the criteria of the learning organizational culture, all of which contribute to the functioning of the knowledge management system. Learning organizations typically employ highly skilled workers whose primary task is to turn information into knowledge and make the most effective use of their competencies. Characteristics of learning organizations: flexible operation and organization, common goals and vision, continuous learning and training, self-management and innovation capacity (Senge 1998).

The most important resource for knowledge-based organizations is human capital, whose knowledge in mind gives the company a competitive advantage - this is where organizational culture, knowledge management and innovation are linked (Lyes 2014). The blending and synergistic application of the knowledge of employees in different fields of the organization has an outstandingly positive effect on innovation performance and thus on competitiveness (Pörzse et al. 2012). So, the most important task of knowledge management is to bring knowledge to the surface, to facilitate knowledge sharing and to ensure the usability of knowledge.

In this chapter will be describe the relevance of knowledge at the company level, the importance of knowledge sharing, organizational culture and learning, and the stimulating effect of the proper operation of the knowledge management system on innovation processes. In the next chapter, will be presented the intertwining of these two areas under the influence of real-life innovation constraints.

\section{Knowledge Management and Innovation in Practice - Primary research}

\section{The knowledge management strategy of the consulting firm under study}

The analyzed company was founded in the early 2000s. According to their portfolio, it mainly offers financial services (sales-business strategy creation, business process automation, developments, etc.), management consulting and business efficiency services (business strategy, process optimization, change management, etc.), business applications and solutions to its customers. The company is headquartered in Budapest and currently works with about 200 consultants. The clientele is very diverse, including finance, telecommunications, automotive and transportation, as well as players in the energy sector and other industrial areas. Like most Hungarian companies, they do not have an independently described knowledge management system or strategy, but knowledge management still appears in the corporate strategy and, for knowledge-based companies, it is an integral part of daily work. The management is aware of the importance of human and knowledge capital - as it is the basis of their activity, competitiveness and profitability - and they try to create and regulate the organizational culture and work processes in such a way that they support the knowledge management activity. A separate paperbased knowledge management strategy was not created because, in their opinion, knowledge management is given sufficient place in the corporate strategy (this is consciously paid attention to), and more important than "regulations" is leadership, established measures and innovative organizational atmosphere. Of course, the fact that the company employs knowledge workers, who, thanks to their professional background, operate the knowledge management and innovation system almost subconsciously, contributes greatly to the operation of knowledge management processes. And how does the management of these systems support the operation of these systems? 


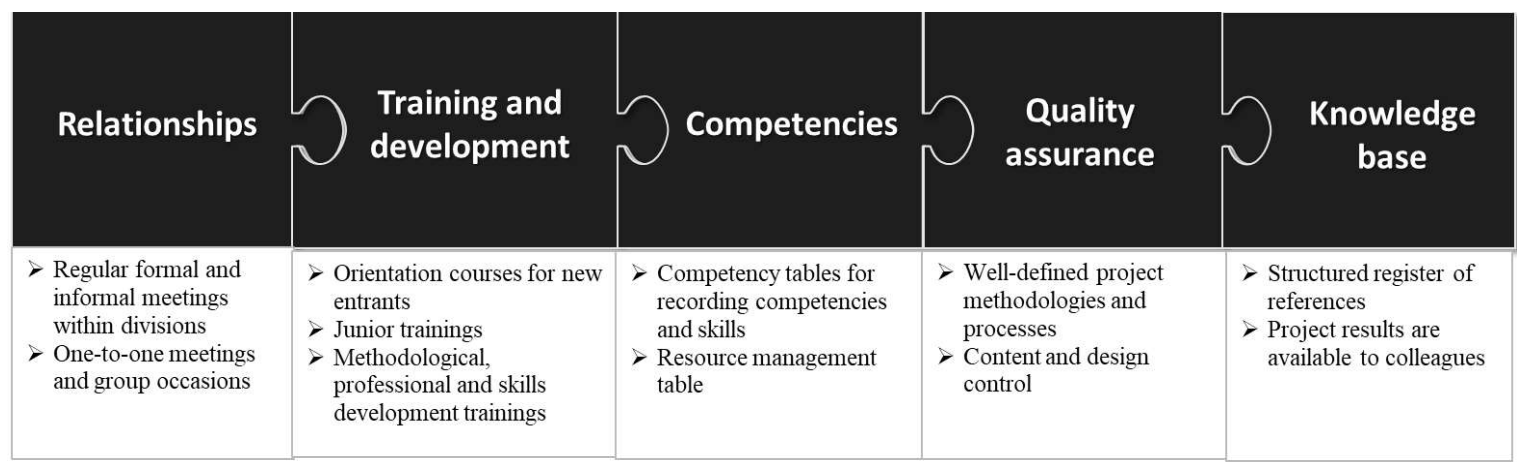

Fig. 2. Representation of knowledge management in organizational strategy

Source: Own editing, based on the training plan of the examined company, 2020

Company managers treat knowledge management goals and activities as an integral part of the company's strategy. In the 2013 forward-looking strategy-making process, the strategic elements that are of key importance in bringing knowledge capital to the surface, knowledge sharing and organizational knowledge management were identified. These are the follows:

\section{Relationships}

For a business consulting firm, building a diversified and appropriate relationship system is paramount, and this can be accomplished in a wellthought-out organizational structure.

Intra-company relationship management is done on an individual and small group basis, as consultants rarely meet with colleagues or work only in a certain team due to the large number of staff and client-side work. Meetings at various levels provide opportunities for networking and feedback.

The organizational structure of the company is sufficiently flat, the consultants can also contact the company managers directly (who also perform Account Manager tasks), so the flow of information and problem management is much more efficient than in a hierarchical arrangement.

\section{Training and development}

As an innovative and knowledge-centric company, it is extremely important to develop an appropriate training plan and to continuously review and implement it. Knowledge is rooted in the learning process, which is realized through the system of training and development and during work. For this reason, it is of paramount importance that the company's training and development plan maximally supports the learning and development of employees, and that their individual development goals are in line with the company's progress goals. In practice, the interdependence of knowledge and innovation management is most clearly embodied here.

The training system can be divided into 3 wellseparated levels, which are developed as follows:

1. Introductory training for new employees, during which the organizational goals and internal processes are described.

2. Methodological, professional and skill trainings for junior and interested counselors. In doing so, they develop basic skills, update and develop methodological knowledge and standardize the methodological background.

3. The knowledge, knowledge and experience gained in the projects are shared in the project application and industry trainings, the building and nurturing of internal relations is realized.

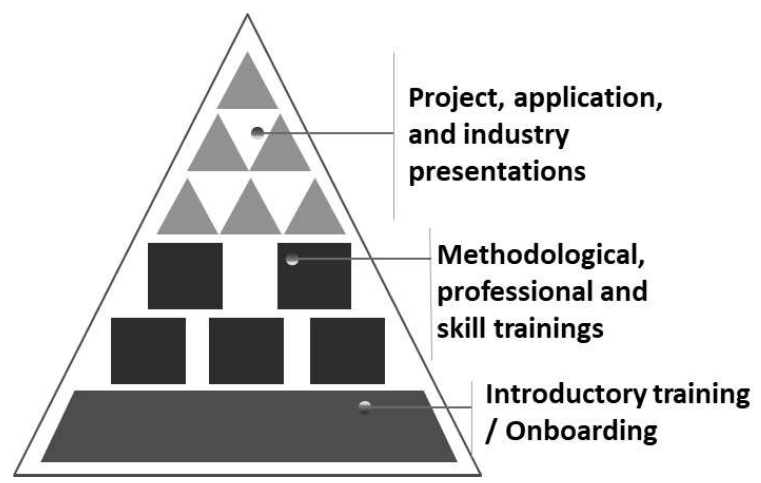

Fig. 3. Training plan and training schedule of the examined company in 2013

Source: Internal material of the examined company from 2013, adapted to this study in 2020 


\section{Competencies}

A competency matrix and a so-called critical resource list are used to record the knowledge, skills and experience of employees for more efficient resource management. The competence matrix contains the skills and experience of the employee in the different fields and modules, as well as the qualifications, language skills and customer experience. With the help of this table, the competencies of the company can be organized, easily filtered and grouped. With such a large number of consulting bases, it is very important to be able to respond with the right resources at the same time as the tasks appear.

The list of critical resources includes the spare capacities of employees. Consultants usually work on several projects at the same time, in different days, it is important to continuously measure and record their available working time. Records support not only efficient resource management but also recruitment and selection.

\section{Quality assurance}

On the one hand, this area includes the company's existing ISO quality assurance certificates. In order to ensure the highest possible quality of service, to increase the existing knowledge base and to facilitate meeting future challenges, a post-project evaluation meeting will be held. At this point, the appropriate conclusions and lessons are drawn from both successes and possible failures, and after evaluating the entire workflow, various methodologies are developed, updated and further developed (eg data migration methodology, project management methodology) and best practice is identified. Methodologies, project evaluation and other additional knowledge materials are uploaded to the company's knowledge base.

\section{Knowledge base}

Similar to the consulting companies with foreign parent companies operating in Hungary, they have access to the international knowledge management network, so if necessary, they can validate the resulting benefits, primarily in terms of methodological and competence access. As a result, members of the international network can also apply for project work for which they may not have the appropriate competence and "hire" the necessary expertise.

Of course, the company also has its own knowledge base, to which the established authorization system is connected as a regulatory function; general knowledge is available to all employees, and knowledge and information related to specific delivery or sales tasks is only available to specific employees. Various methodologies, presentation materials, industry reports, quality assurance requirements, procedures, process descriptions, training materials, and other professional tools (applications, utility program descriptions, installation guides, etc.) that are stored in a file directory accessible to all employees. An important element of the corporate knowledge base is also the reference register of previous projects as well.

\section{Implementing AFR innovation by supporting a knowledge management system}

From July 2019, there were significant changes in the life of financial institutions. The National Bank of Hungary (MNB) publicated a new regulation for $35 / 2017$. (XII.14.) regulation on payment transactions. According to this, financial institutions domiciled in Hungary must provide the so-called The "immediate transfer" condition, which requires a transfer between bank accounts within 5 seconds. The same applies to all financial institutions domiciled in Hungary, every day of the year, 24/7. (AFR). (www.net.jogtar.hu) In order to ensure immediate transfer, banks need to make very serious improvements in their payment systems, which will greatly change the operation of their internal corporate governance systems. As a multifunctional specialist with excellent IT and payroll skills is needed to solve the task (who embrace the project from concrete development to change management), banks have turned to consulting firms for help.

Before a consulting firm puts in place the first suitable system, it must invest significant resources in order to be able to apply and win a job of this level at all. And the quality and operation of the knowledge management system and resource management becomes a matter of life in situations like this.

Based on previous experience, the management of the company started preparing after the arrival of the first news and set the goal of providing the most competitive range of solutions. Due to the size of the task, the preparation took almost a year and during this time the expectations of the legislator were constantly changing, refined, and clarified, both in terms of the processes and the technical parameters of the new system.

The innovation process that enables the creation of the innovation solution and the implementation of the project and the operation of the knowledge management system serving it is summarized in the following figure.

Prior to the implementation of innovation projects that allow immediate reference, the following knowledge management processes take place at a given company:

I. Collection of information in preparation for a decision

The publication of the MNB regulation formalized the company's cash flow innovation objectives, however, detailed data and information on practical operations are not yet available at that time. The management team primarily researches foreign examples and primarily inquires about opportunities with clients. Second, they need to examine what competencies are available for the preparatory tasks and then for the project execution; examination of external and internal resources, assessment of recruitment opportunities, examination of return on investment are necessary. 
After examining their options based on public information, a strategic decision is made; whether they wish to participate in these development projects. As the company already has similar experience, the appropriate banking knowledge and network of contacts, and the resources needed to prepare the project (additional resources need to be recruited to implement the project), management will appoint a professional in charge of the preparation tasks.
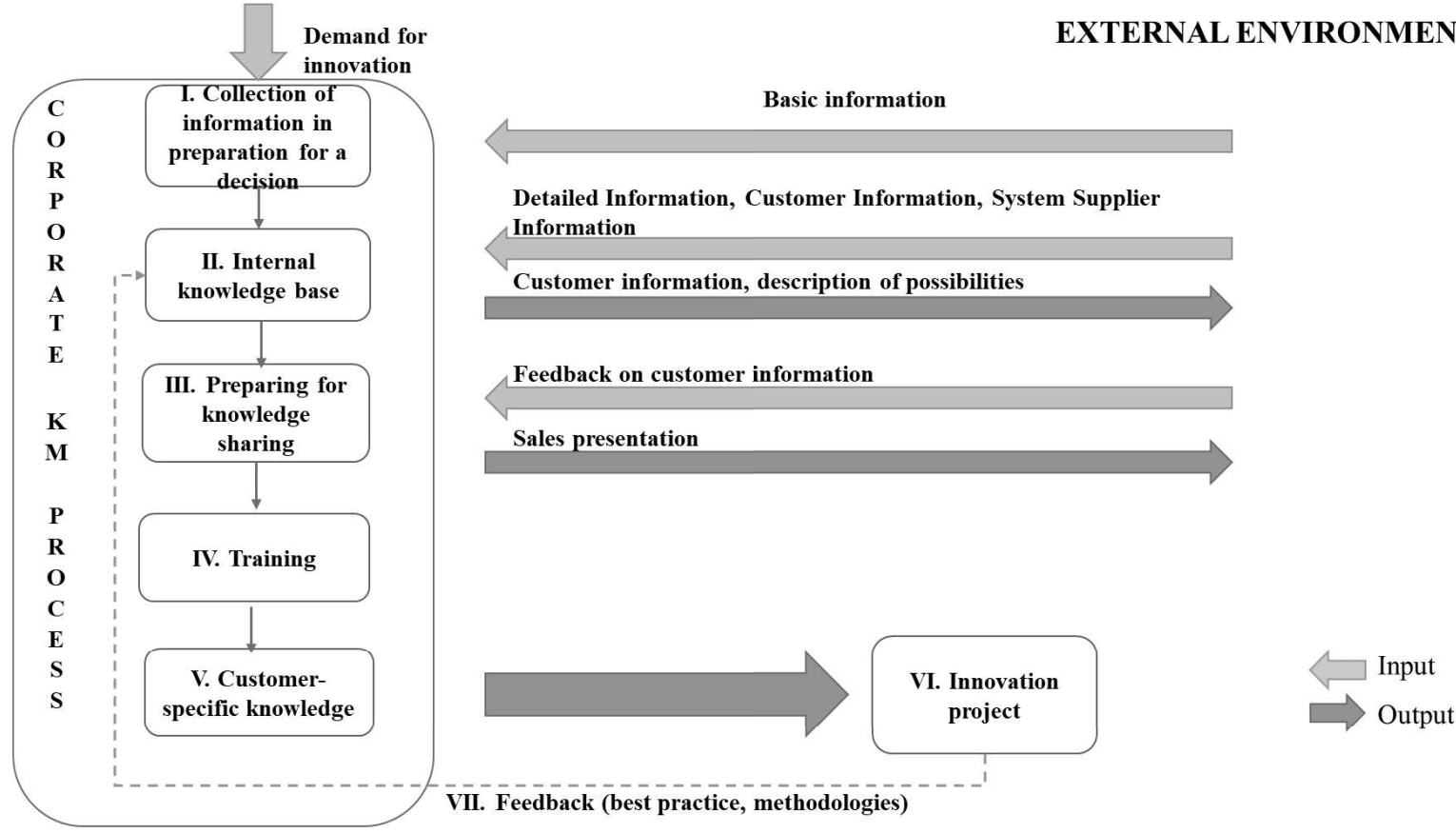

Fig. 4. The innovation process of the examined company Source: Own editing, 2020

\section{Building an internal knowledge base}

The responsible person with dedicated professional expertise will continue to gather knowledge and information. It explores different cases and suggests solutions. Once he or she has gathered the appropriate amount of knowledge, the company-appointed executives will retain the first internal information on the subject. This briefing will be attended by operational management experts on the one hand and operational payment experts on the other.

From this, a working group of 5-6 people will be formed from the payment experts, who will start collecting information on the client side under the hands of the professional manager; knowledge transfer and accumulation take place at the same time. Consultants lay the groundwork for the sales process; they inform the client-side experts about the expected size of the task, the challenges, the problems, the known solution options, and the client also shares with them any internal information that contributes to even more accurate knowledge and finding the most suitable solution. Meanwhile, the relevant Account Managers and the professional in charge participate in conferences and presentations related to the innovation task, and contact the client-side IT managers, who are responsible for the tenders and decisions to be announced on the topic. In this way, they manage to draw attention to the importance and urgency of the issue, as well as the resulting opportunities, at both the managerial and employee levels.
In parallel, management will contact system supplier companies, that offer current banking systems or possible external solutions; collect the necessary data and discuss possible options.

The professional in charge monitors legal / regulatory changes throughout the process.

III. Preparing for knowledge sharing

After building the internal knowledge base, the next task of the professional working group is to prepare the internal educational material. For this, they use customer-side information from sales presentations and what was said in negotiations with customers. During these negotiations, the Account Manager is always accompanied by an expert from the working group. The group is constantly exploring possible solutions and is also trying to bring to light any hidden competencies that may be available.

As project opportunities are outlined, the HR department begins recruiting the missing resources.

\section{Training}

Once the educational material prepared by the working group has been completed, the knowledge gathered will be shared more widely ( $40-50$ people). At this time, the ideas and plans of some clients are also discussed as a case study, and participants share both their professional and client-specific knowledge and previous experiences (IG2). Extensive training is successfully created to create project teams who can perform various tasks later. 
V. Customer-specific knowledge

Following the sales presentations and negotiations, the various customer needs are formulated and the first tenders on the topic are announced.

Two standard tendering procedures are launched:

a) the customer has stated which solution he prefers, and

b) he is waiting for a proposal for the most appropriate solution.

The bidding process has a separate process in which the professional part (details of the implementation of the proposed solution, professional and resource conditions, requirements) is invented and put together by each member of the working group (in constant consultation with the entire working group and the professional responsible). Their work is supported by the experience, system knowledge and relationships of the consultants who are actively working on the client side. The sales department administratively supports the process; provides the necessary quality assurance and financial certificates, the competence matrix of the recommended specialists, their professional CVs, and they help to prepare the commercial offer.

After the evaluation of the bids, if the company is chosen as a partner, the preparation of the project will start:

- assigning the necessary resources to the project, recruiting, selecting and hiring new employees if necessary,

- training / further training of resources on customer-specific requirements for immediate referral, customer systems, solutions, required modules, etc.,

- continuous consultations with client-side experts and responsible persons.

VI. Implementation of the innovation project

"Real" knowledge transfer and learning takes place during the duration of the project; for experiential knowledge is much easier to fix and provides an opportunity for continuous development, both at the individual and organizational level. According to the Center for Creative Leadership's 70-20-10 model, 70\% of employees learn the most in the course of their

\section{Conclusions, suggestions}

The innovation process is based on the operation of the knowledge management system. If the system does not work properly or the necessary decisions are not made in a timely manner, the company will run at a serious disadvantage over well-responsive competitors. The task of a knowledge management system is to gather the right information in a timely manner, to see the necessary competencies and to create and make available the knowledge necessary for innovation. Relationships with the corporate environment, legal / regulatory system, customers and competitors are also prerequisites for success in terms of information flow, mapping opportunities and solutions.

As evidenced by the number of successful projects, sales data, and a growing clientele, the company has properly assessed its capabilities, strategic goals, and knowledge management system to successfully apply work, $20 \%$ oppose the way others work, while only $10 \%$ acquire knowledge through theoretical, formal training. (22) Junior advisors are sponsored by seniors, and payment experts teach client-side IT experts the knowledge necessary for the success of a given project and its future use.

During the implementation of the innovation project, presentations and professional materials are created, workshops and discussions are organized periodically or as needed.

VII. Expansion of knowledge base, knowledge sharing

During the project, meetings are held regularly not only at the client, but also within the company, where they analyze and evaluate the progress and schedule of the project, new information that comes to the surface, the problematic situations that have arisen and possible future obstacles.

Once the project is completed, the consultants involved in the project and the members of the professional working group, together with the management, carry out a full analysis and evaluation of the project, creating, updating and expanding methodologies, increasing the company's knowledge base and success.

Customers are asked by the sales department for a recommendation, which is also recorded in the register of company references. Based on the acquired knowledge material and the conclusions drawn, the educational material is finalized and the sales presentation is updated.

It is clear from the schedule that the different steps run in parallel, and the knowledge base is fine-tuned and expanded during and after the project. In addition, consulting companies not only implement innovation projects at several clients at the same time, but also in several different areas and industries. A high level of coordination on the part of management and the ability to select and retain the right resource are necessary for the company's standing and competitiveness.

innovation processes. Employees also experience the preparation / project deliveries of such projects as an individual and professional challenge and this greatly contributes to reducing turnover. However, in making decisions about knowledge sharing, users are not yet fully independent, automated (hence the need for teamwork) and there are still areas for improvement in terms of participation. Internal trainings are mostly held by company staff, which presupposes an advanced knowledge-sharing ability and willingness on the part of the presenter, but efforts should also be made to activate a passive audience; everyone must be involved in building and expanding organizational memory.

The company has an internal network and employees have the right access to it. Qualitative measurements are used to monitor the development of employees and their contribution to organizational goals, which is also a very important step.

In order for the consulting company to maintain its competitive advantage and innovation capacity in the 
knowledge management system in the future, the following measures can be recommended:

- company management should constantly set an example, and it would be worth highlighting the importance and opportunities of e-learning; encourage their staff to take advantage of e-learning and to be active participants in expanding the knowledge base;

- link the individual learning even more to performance appraisal; this will make it easier for workers to understand their skills and help them achieve better performance;

- The 'learning is a game' program: levels can be achieved through various vocational training courses, and rewarding all levels is rewarding;

- introduction of a mentor program; by recognizing the professional experience of senior counselors, the integration, training and development of junior counselors can be enhanced with outstanding efficiency, and thus loyalty and motivation also increase at the organizational level;

- building a universal knowledge management network at the international level, which can be routinely managed by all employees of the subsidiaries, and have direct access;

- those working in knowledge-intensive jobs are flooded with a multitude of information on a daily basis, so it is very important to be able to filter, search and integrate information in the knowledge base with sufficient accuracy and speed; continuously improve the efficiency of the internal knowledge base;

- create professional community portals, where specialists from different fields can share the results of their individual research and training, their opinions on future innovations and solutions;

- it would be worthwhile to conclude cooperation agreements with universities and academic student groups so that the next generation would strengthen the company's competencies.

The aim of the study was to examine the innovation-enhancing effect of knowledge management. In order to prove this, it has been tried to provide the most comprehensive literature review possible, which is not exhaustive and should be further expanded and detailed in the case of possible future research. The authors are belive that they established the usefulness and problems of the topic and in formulating useful proposals that will increase the company's further development and innovation skills

\section{Bibliography}

35/2017. (XII. 14.) MNB rendelet a pénzforgalom lebonyolitásáról, (MNB Decree ont he processing of payment trasaction) https://net.jogtar.hu/jogszabaly?docid=A1700035.MNB\& by analyzing the innovation process that will enable the implementation of the banking development project.

After examining the literature, it has been briefly presented the consulting firm under study. Then examined and illustrated the mapping of knowledge management in corporate strategy, which affects several areas; relationships, training and development, competencies, quality assurance and the knowledge base. The listed areas were also analyzed individually.

After this, the study turned to the practical presentation of the innovation-enhancing effect of the knowledge management system: from summer of 2019 the bank transfers must be completed within 5 seconds according to the 35/2017. (XII.14.) regulation of the National Bank of Hungary. The set innovation goal requires a very complex implementation, and the banks - among other things - turned to the surveyed company for help. Based on the knowledge management system and previous experience of the consulting company, it fulfilled the task born of the innovation constraint. An analyzation process went through and examined the innovation process used for the solution, and then, in the light of the above, and the analyzator's team came back with some conclusions and suggestions.

The investigation and results of the study suggest that the introduction of innovative solutions with a similar scope and significance to the AFR requirement requires a well-developed knowledge management coordination capability on the part of corporate management.

On the employee side, a combination of maximum professionalism and value creation intent is essential. The implementation of goals, plans and developments can be based on a knowledge management system, the creators / implementers / operators of which are aware of the importance of knowledge capital, the difficulties of knowledge sharing and the impact of innovation on competitiveness.

The conclusion is about the examined company has a desire for continuous improvement and improvement on the part of the company management and they also support the employee initiatives for this purpose on a daily basis.

It can be stated that the innovation described by the literature is the most important development for the analyzed company, but in its internal practice and communication, new or re-examined processes appear as innovations.

In the near future, the main challenge will be to motivate and activate employees as effectively as possible, and to support alternative learning opportunities. By further developing their knowledge management system, they can ensure their ability to innovate and their leading market position. timeshift $=$ fffffff $4 \&$ txtreferer $=00000001 . T X T$ downloaded: 26/09/2020

Balaton, K., Hortoványi, K., Incze, E., Laczkó, M., Szabó, Zs..R., Tari, E. (2010). Stratégiai menedzsment, (Strategic management), Aula, Budapest. 
Bencsik, A (2018). The relationship of knowledge management and innovation. In: Juhász, T. (ed.) Studies about the Perspectives of Social Sciences. Szent István University,Gödöllö: pp. 2-20., p. 137

Bencsik, A. (2011). Amiröl keveset beszélünk... Az etika értékeinek érvényesülése a tudásmenedzsmentben, (What we talk about little-Enforcing the values of ethics in knowledge management), Humánpolitikai Szemle. October, page 3 .

Bencsik, A. (2015). A tudásmenedzsment elméletben és gyakorlatban, (The knowledge management in theory and practice) -Akadémiai Kiadó, Budapest, 20.p.,320 p.

Bencsik, A., Für, K. (2015). Olcsó és okos- a frugal innováció és a tudásmenedzsment szimbiózisa (Cheap and smart - a symbiosis of frugal innovation and knowledge management), Vezetéstudomány . 12. no., 4151.pp.

Bencsik, A., Juhász, T. (2012). Tudásmenedzsment és HR a 21. században (Kowledge management and HR in the 21st century). Humánpolitikai Szemle, November, p. 16.

BMVK (2007). Az innováció. Vállalkozásfejlesztési oktatási jegyzet, Baranya Megyei Vállalkozói Központ (nnovation. Entrepreneurship Development Education Note, Baranya County Entrepreneurship Center), http://bmvk.hu/downloads/online_tudastar/innovacio.pdf , Pécs, p.6.

Csath, M., Fási, Cs., Nagy, B., Pálfi, N., Taksás, B., Vinogradov, S. (2018). The role of knowledge and value intangibles in the age of great changes: the case of Hungary in international comparison, KÖZ-GAZDASÁG XIII: 3, p. 29-46.

Chikán, A. (2017). Vállalatgazdaságtan (Business Ecomics), Corvinus Kiadó, Budapest. p.320.

Chikán, A., Czakó, E. (2009). Versenyben a világgal: vállalatok versenyképessége az új évezred küszöbén (Competing with the world: the competitiveness of companies on the threshold of the new millennium), Akadémiai Kiadó, Budapest.

Csiszér, T.(2011). Tudásmenedzsment - A valódi értékteremtés záloga,( Knowledge Management - The key to real value creation) https://www.hrportal.hu/hr/tudasmenedzsment-a-valodiertekteremtes-zaloga-20110124.html , downloaded: $22 / 03 / 2018$

Davenport, T. H., Prusak, L. (2001). Tudásmenedzsment. (Knowledge management), Kossuth Kiadó, Budapest.

European Innovation Scoreboard 2017, Source: http://ec.europa.eu/growth/industry/innovation/factsfigures/scoreboards_hu, downloaded: 18/04/2018

Fejes, J.(2015). A tudásmenedzsment fejlődési szakaszainak tettenérése a magyar üzleti tanácsadás piacán, (The development stages of knowledge management in the Hungarian business consulting market), Vezetéstudomány. VIII no., pp. 24-32.

Fenyvesi É., Kárpátiné Daróczi J., Vágány J.(2015). Do we develop for the sake of development? Or what kind of training methods do leaders prefer today. Science Journal of Business and Management. 3(1-1): p59-65 doi: 10.11648/j.sjbm.s.2015030101.20 Internal matter Company presentation of the examined company, 2017, Budapest.

Kis, G., Lőrincz, V. (2007). Innovációs trendek. (Innovations Trends) GKIeNET. Internetkutató és Tanácsadó $\mathrm{Kft}$. $\mathrm{http} / / /$ docplayer.hu/746459-Innovacios-trendek-ibmmagyarorszag-gkienet-magyarorszag.html, downloaded: $20 / 014 / 2018$
Kiss J. (2014): Vállalati versenyképesség és innováció, TM 30.sz. mühelytanulmány (Corporate Competitiveness and Innovation, TM No. 30 workshop study). Vezetéstudomány. In: Sára, Z., Csedő, Z., Fejes, J., Tóth, T., Pörzse, G.: Innovációmenedzsment és innovációs stratégiák- $A$ vállalati tudás szerepe az innovációs folyamatokban (Innovation Management and Innovation Strategies- The Role of Corporate Knowledge in Innovation Processes). BCE, Budapest. X. no. pp. 42-48)

Kiss. J. (2005). A magyar vállalatok innovációs tevékenysége,( Innovation activity of Hungarian companies), BCE Versenyképességi Kutató Központ (Competitiveness Research Center), Budapest.

Kiss. J.(2014). A magyarországi vállalatok $\mathrm{K}+\mathrm{F}$ és innovációs teljesítménye, 112. no. mühelytanulmány (R\&D and innovation performance of Hungarian companies, 112. no. workshop study). Vezetéstudomány. In Sára, Z., Csedő, Z., Fejes, J., Tóth, T., Pörzse, G.: Innovációmenedzsment és innovációs stratégiák- A vállalati tudás szerepe az innovációs folyamatokban (Innovation management and innovation strategies- The role of corporate knowledge in innovation processes). $\mathrm{X}$. no,. pp. 1-9., pp. 42-48.

Kleina, D., Štale, S. (2019). Motivational Factors of Employees in Latvian Labor Market. Vadyba Journal of Management., Vol. 35, No. 2 ISSN 1648-7974, pp27-36

Lyes, M. A. (2014). Organizational Learning, knowledge creation, problem formulation and innovation in messy problems. European Management Journal.. p.32, p. 132136.

Marosi I. (2015). Innovation goals and practices among hungarian small and medium enterprises, proceedings of FIKUSZ 13. Vezetéstudomány. in: Michelberger, P. (ed.): Proceeding of FIKUSZ, 13., Budapest, Óbuda University, Keleti Faculty of Business and Management, p: 7-18. In: Bencsik, A., Für K.: Olcsó és okos- a frugal innováció és a tudásmenedzsment szimbiózisa(Cheap and smart - a symbiosis of frugal innovation and knowledge management)

Nathan, R. J., Yi, C. X., Hegyesné, G. É., Vijay, V., Gonda, GY., Fekete F. M. (2019). Impact of Knowledge and Innovation Management to Firm Financial and NonFinancial Performance 12 . no. Vadyba Journal of Management., Vol. 35, No. 2 ISSN 16487974,pp 71-83.

Pörzse, G., Takács, S., Csedő, Z., Sára, Z., Fejes, J.(2012). The impact of creative organizational climate on the innovation activity of medical device manufacturing firms in Hungary. European Journal of Business and Management, Vol. 4, No. 13.

Sára, Z., Csedő, Z., Fejes, J., Tóth, T., Pörzse, G. (2014). Innovációmenedzsment és innovációs stratégiák- A vállalati tudás szerepe az innovációs folyamatokban (Theory and practice of learning organization formationInnovation management and innovation strategies- The role of corporate knowledge in innovation processes). Vezetéstudomány. X. no., pp. 42-48.

Schwartz, D.(2006). Encyclopedia of Knowledge Management, Idea Group Inc. (IGI), New York.

Senge, P.M. (1998). Az 5. alapelv. A tanuló szervezet kialakitásának elmélete és gyakorlata (Theory and practice of learning organization formation). HVG Rt., Budapest.

Vecsenyi, J. (2003). Vállalkozás - Az ötlettöl az újrakezdésig.(Innovation. Business Development Education NoteEnterprise - From idea to restart) Aula, Budapest. 
Mónika Pónusz. PhD, associate professor, Károli Gáspár University of the Reformed Church in Hungary Institute of Economics and Management, Deputy Head of Institute -Education and Studies, Field of scientific research: logistics, innovation management, supply chain management, sustainable development, Industry 4.0, She has more than 15 years experience in B2B sector by multinational companies ponusz.monika@kre.hu, H-1042 Budapest, Viola str. 2-4.

Anna Rittgasser. Graduated student in Economist BA in Human Resources, Károli Gáspár Reformed University, Faculty of Law, Institute of Economics and Management, anna.rittgasser@gmail.com.'H-1042 Budapest, Viola str. 2-4.

Vivien Ágnes Nagy. PhD student, University of Szent István Faculty of Economics and Social Sciences - Doctoral School of Managemenet and Business Administration She has been working in logistics for 12 years and will continue her studies in this field, within the topic of green technological innovations in the supply chain., nagyvivienagnes@gmail.com H-2100 Gödöllö Páter Károly utca 1.

Tímea Kozma. PhD, associate professor, Budapest Business School FACULTY OF FINANCE AND ACCOUNTING; Her areas of research include Supply Chain Management, Strategies and Life-cycle of Small and Medium Enterprises, Quality Management. kozma.timea@uni-bge.hu, H-1149, Budapest, Buzogány u. 10-12. 